\title{
The Effectiveness of Online Based Physics Learning in The Covid-19 Pandemic Period on The Material of OJS Work and Energy

\author{
Kharisma Titian Haqiqi ${ }^{*}$, Eko Hariyono, Nurita Apridiana Lestari \\ Jurusan Fisika, FMIPA, Universitas Negeri Surabaya \\ Jl. Ketintang, Surabaya 60231, Indonesia \\ *Email: kharisma.17030184052@mhs.unesa.ac.id
}

DOI: https://doi.org/10.33369/pendipa.5.3.451-458

\begin{abstract}
The Covid-19 pandemic that hit Indonesia impacts the field of education. The learning process is usually carried out face-to-face has turned into online learning. This study aims to see the effectiveness of online learning based on the learning process, the achievement of learning objectives, and the obstacles experienced by students and teachers when doing online learning at SMA Negeri 2 Ponorogo during the Covid-19 pandemic. The quantitative descriptive method was used in this research. The online survey was used by using a questionnaire instrument through Google Form and cognitive tests. The results showed that online learning during the Covid-19 pandemic often used the WhatsApp platform and school elearning websites. Respondents were interested in taking physics lessons during the pandemic online because respondents used many learning medias. Based on the cognitive test results, the mean value of the respondents was $<60$ and did not meet the graduation criteria. The result shows that the respondents do not understand the materialof work and energy. The obstacles experienced by respondents were difficulty understanding the material and questions in the form of statements on work and energy materials and limited quotas and internet networks. Based on the questionnaire, it was found that the effectiveness of online learning was 57\%. It can be concluded that online-based physics learning during the Covid-19 pandemic at SMA Negeri 2 Ponorogo on adequate energy and business materials was carried out as a substitute for face-to-face loffline learning.
\end{abstract}

Keywords: Learning physics, online, work, and energy.

\begin{abstract}
ABSTRAK
Pandemi covid-19 yang melanda Indonesia berdampak pada dunia pendidikan proses pembelajaran yang biasa dialkukan dengan tatap muka berubah menjadi pembeljaran daring. Penelitian ini bertujuan untuk melihat efektivitas pembelajaran daring berdasarkan proses pembelajaran, pencapaian tujuan pembelajaran dan kendala yang dialami oleh siswa dan guru pada saat melakukan pembelajaran daring di SMA Negeri 2 Ponorogo selama pandemi covid-19. Penelitian dilakukan dengan menggunakan metode deskriptif kuantitatif. Teknik pengumpulan data dengan metode survei secara online menggunakan instrumen kuisioner melalui Google Form dan test kognitif. Hasil penelitian menunjukkan bahwa pembelajaran daring saat pandemi Covid-19 sering menggunakan platform whatsapps dan website elearning sekolah. Responden tertarik mengikuti pembelajaran fisika selama pandemi dengan daring dikarenakan banyak media pembelajaran yang digunakan. Berdasarkan hasil test kognitif menunjukkan nilai rerata responden $<60$ dan tidak memenuhi kriteria kelulusan. Hal ini menujukkan responden kurang memahami materi usaha dan energi yang diberikan. Adapun kendala yang dialami responden yaitu sulit memahami materi dan soal yang berupa pernyataan pada materi usaha dan energi serta keterbatasan kuota serta jaringan internet. Berdasarkan angket didapatkan nilai efektivitas pembelajaran daring sebesar 57\%. Berdasarkan data penelitian dapat disimpulkan bahwa pembelajaran fisika berbasis daring saat masa pandemi covid-19 di SMA Negeri 2 Ponorogo pada materi usaha dan energi efektif dilakukan sebagai pengganti pembelajaran tatap muka.
\end{abstract}

Kata Kunci: Pembelajaran fisika, Daring, Usaha dan energi 


\section{INTRODUCTION}

Indonesia has experienced the Covid-19 pandemic since March 2020. Based on data from the Covid-19 handling task force, it recorded that more than 1.48 million Indonesians are infected with the Covid-19 virus (covid19.go.id update March 23, 2021). The large number of Indonesians who have contracted the Covid -19 virus impacts all aspects of Indonesian people's life. There have been changes in the activities and lifestyle of the community to prevent transmission of the covid-19 virus. This change also occurs in the field of education. Since March 2020, the Government has decided to close schools temporarily. Based on data from the United Nations Educational, Scientific, and Cultural Organization (UNESCO), there are at least 290.5 million students worldwide whose learning activities were disrupted due to closed schools (Purwanto et al., 2020). The World Health Organization (WHO) states that the current pandemic cannot be ascertained when it will end. The situation makes the Government have to take action for the continuity of education in Indonesia. Amid an increasingly worsening pandemic situation, the Government finally has to make an online or online learning policy to replace traditional face-to-face learning to ensure students continue to get learning (Herliandry et al., 2020; Irhandayaningsih, 2020; Mustakim, 2020 ). On March 24, 2020, the Minister of Education and Culture of the Republic of Indonesia issued Circular Number 4 of 2020 concerning the Implementation of Education Policies in an Emergency for the Spread of COVID-19. In Circular, it explained that the learning process is carried out at home through online / distance learning to provide experience to students. Education directed at understanding the spread and prevention of the coronavirus outbreak.

The implementation of online learning in Indonesia, which was carried out, suddenly caused several problems. Online learning is followed by good technology and good human resource readiness. Online learning makes excellent use of the internet network. Meanwhile, in Indonesia, there is no internet network evenly, especially in rural areas. This factor is what disrupts the online learning process. The ability of teachers and students to take advantage of technology is also not optimal, causing learning to sometimes not run smoothly. Such a situation opens the opportunity to research online learning to be more effectively applied in times of a pandemic.

Based on research conducted by Abidin (2020) and Darmayanti (2020), online learning during the Covid-19 pandemic was sufficient to replace face-to-face learning. However, when viewed from its effectiveness, online education has not been able to achieve learning objectives. Several factors are inhibiting the achievement of learning objectives, such as the unpreparedness of teachers and students in terms of ability to use technology and the availability of learning facilities such as poor internet networks in their homes, and the limited economy of students and teachers who have not been able to support the learning process. Kurniawan (2020) also mentions that the ability of teachers and students to take advantage of IT and poor internet networks in various places is an inhibiting factor in the online learning process.

Research also conducted by Rachmat (2020) states that online learning is less effective and can be seen from students' lack of understanding in education. The effectiveness of online learning during the Covid-19 pandemic is by using the Google Classroom application and the learning model using modules and books held by students, and the types of assignments that students can understand are multiple-choice question assignments. This statement is in line with research conducted by Abidin (2020), which states that many platforms can be used as online learning media, such as Google Classroom and Edmodo, which can be accessed for free.

Based on the results of research by Kusuma (2020), online learning using quizzes on work and energy materials are effective. Students will be motivated to improve their learning outcomes and understand the subject matter of effort and energy. Yunita's research results (2021) state that using learning media in videos containing work and energy materials on Youtube can make it easier for students to understand work and energy materials. Nasution (2019) states that the use of Edmodo for work and energy materials is considered adequate because it can teach basic understanding so that it can minimize the use of 
online meeting time and can make learning without the limitations of space and time.

So far, many studies show that the online learning process is considered quite effective. However, some obstacles are still found, including a lack of student understanding of the material taught by the teacher. Seeing this problem, researchers want to provide an overview of online learning in Ponorogo Regency. The purpose of this research is seeing online-based physics learning has been effectively implemented according to the perspective of students who live in all areas of Ponorogo Regency. One of the schools that conducted online learning during this pandemic was SMA Negeri 2 Ponorogo. Researchers want to see from the student's point of view, the effectiveness of online learning carried out by schools from the student's ability to use online learning media, the convenience of implementing online learning, and learning objectives that can be achieved with online learning methods that have been implemented primarily on work and energy materials. This research is expected to help provide additional information regarding the effectiveness of online-based physics learning in Indonesia, incredibly high schools on work and energy materials.

\section{METHODS}

The research method used in this research is descriptive quantitative. The population of this study was all students of class X MIPA at SMA Negeri 2 Ponorogo. The sample was expected to represent the population in the research carried out to become a picture of the existing population. To determine the number of samples to be taken in this study using random sampling, select students of class X MIPA 3 as many as 36 students.

The research data of this study are primary data with a survey method that uses a questionnaire as a tool to collect data. This study uses an online questionnaire with Google Form to be distributed to respondents so that during the COVID-19 pandemic, respondents can fill out questionnaires from their respective places of residence. The questionnaire consists of 16 open questions and 15 closed questions using a Likert scale. The researcher used the Likert scale to measure a person's attitudes, perceptions, and opinions of a social phenomenon. The aspects of learning objectives, time efficiency, and the situation of online education were made looked at by the questionnaire. The answer choices provided Strongly Agree (SS), Agree (S), Disagree (TS), and Strongly Disagree (STS). The data will be analyzed by the descriptive method using the mean value to know the description of online-based physics learning during the Covid19 pandemic. The categorization of the effectiveness of online-based physics learning during the Covid-19 pandemic is shown in the table 1 .

Table 1. Interval of the effectiveness on online physics learning scores

\begin{tabular}{|l|l|}
\hline Score Interval & Category \\
\hline $76 \%-100 \%$ & Very good \\
\hline $51 \%-75 \%$ & Good \\
\hline $26 \%-50 \%$ & Good enough \\
\hline $0 \%-25 \%$ & Less \\
\hline
\end{tabular}

Source: (Widoyoko, 2009)

This study also used a test consisting of 10 multiple choice questions and used the school's e-learning website. The test is used determine students' understanding on the material of the work and energy. The data will be collected, reviewed, and analyzed to get results and conclusions about the effectiveness of onlinebased physics learning.

\section{RESULT AND DISCUSSION}

The research respondents were students of class X MIPA 3 at SMA Negeri 2 Ponorogo. The number of respondents who took part in this study amounted to 36 students. Data were collected by distributing questionnaires through Google Form and giving cognitive tests to students to obtain the following results.

Based on the survey results, respondents answered that all learning activities were carried out online and used several platforms as learning media. Figure 1 shows that as many as 20 respondents answered using Whatsapp as the most frequently used learning platform, and 19 answered using e-learning as a learning medium that is often done, so it can be concluded that students and teachers use Whatsapp more often and e-learning as a learning platform-often used. According to Kusuma (2020), students are 
more interested in using e-learning websites because students can measure their abilities and reflect on studying harder. The survey also stated students' interest in learning physics in onlinebased work and energy materials during the Covid-19 pandemic. Based on the respondents' interest in online learning, the following results were obtained.

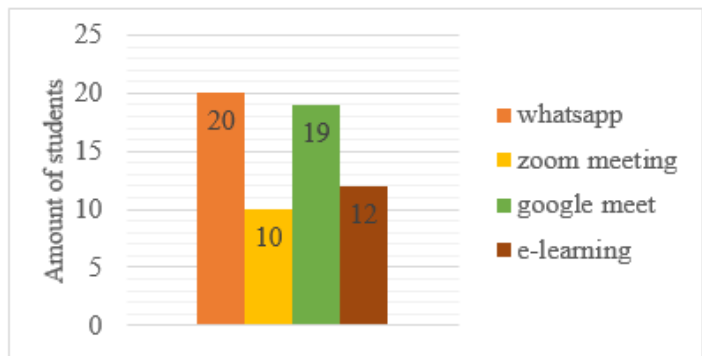

Figure 1. The platform that is often used during the learning process

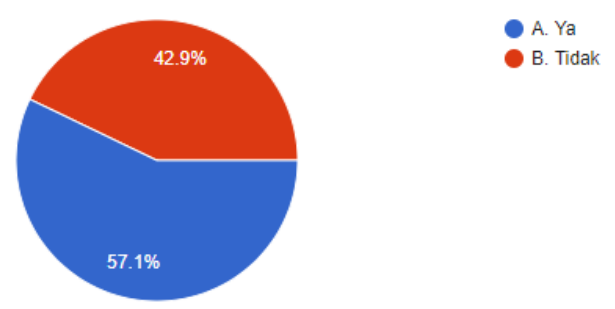

Figure 2. Students' interest in taking online learning

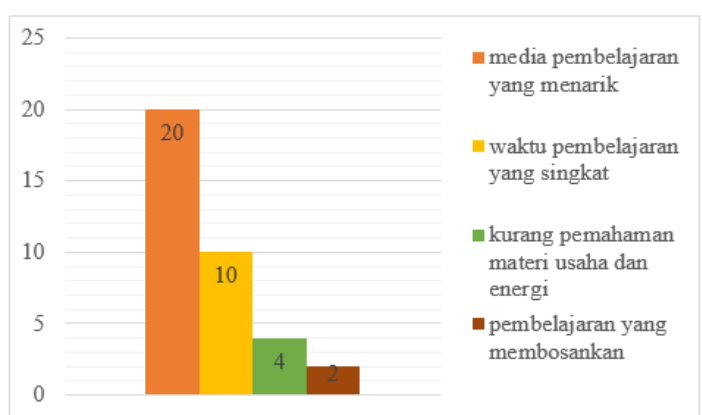

Figure 3. The reasons for students' interest in learning physics online

Based on Figure 2, as many as $57.1 \%$ of respondents said they were interested in online learning, and $42.9 \%$ answered that they were not interested. Respondents who answered that they were interested in taking physics learning on work and energy materials online as many as 20 respondents thought the teacher used many media such as videos, books, and exciting powerpoints, and ten respondents believed that the short lesson hours made respondents very interested in learning physics online. The teacher uses the school's e-learning website to upload teaching media. In the teacher's effort and energy material, a video contains an exciting and detailed explanation of the material. The video also includes an animation that makes it easier for students to understand work and energy materials. Based on the results of Yalensi's (2020) study, learning videos accompanied by animation, audio, and text can arouse and increase student motivation to learn. Assignments are carried out by uploading quizzes and questions of understanding on the elearning website so that students can access and work on quizzes and questions at any time. Based on Rasyidah's (2018) research, creative learning media is needed so that students are interested and do not get bored quickly. According to a study conducted by Hikmat (2020) says that online learning can be effective. Its implementation was planned, starting from the readiness of students and teachers and teaching materials and teacher creativity so that students can understand the material well. Respondents who answered that they were not interested argued that the respondents had difficulty understanding the material because it was not delivered directly. The respondents considered too many assignments given so that the respondents only learned when there was an assignment. As many as two respondents answered that online learning feels very dull. The following research conducted by Daheri (2020) states that online learning that often uses WhatsApp as an online learning medium is less effective in achieving learning goals because of the lack of direct explanation from the teacher, low affective and psychomotor aspects, and internet networks.

Based on the questions using the Linkert scale, the results showed that the average score was $57.65 \%$, so it can be said that the onlinebased physics learning process during the Covid19 pandemic was categorized as good. The result followed the respondent's opinion that the teacher is very active in providing interesting work materials and energy accompanied by tasks 
that enhance the respondent's cognitive. Wajong (2020) states that online learning requires the creativity of students and teachers' activity when carrying out the learning process.

This research uses energy and work materials, including the amount of work, mechanical energy, kinetic energy, and potential energy. Work can be defined as energy changes or mathematically the multiplication between the force and the displacement at which the force acts (Tipler, 1998: 156). Kinetic energy means the energy that an object has when it moves, a set of potential energy defined as the energy that an object has because of its position in the reference plane (Kanginan, 2007; Raharja, 2014). In the learning process, the teacher provides a video containing an explanation of the meaning of effort and energy and its application in everyday life. The teacher provides an example of an experiment through Phet so that students understand the material more easily. In this study, a cognitive assessment was carried out by distributing ten questions in multiple choices to measure students' understanding of the work and energy materials. Based on the cognitive test results, the mean score of students was $<60$ and did not meet the passing criteria, which were 78 . Many respondents answered incorrectly on questions number 9 and 10 , as for questions number 9 and 10.

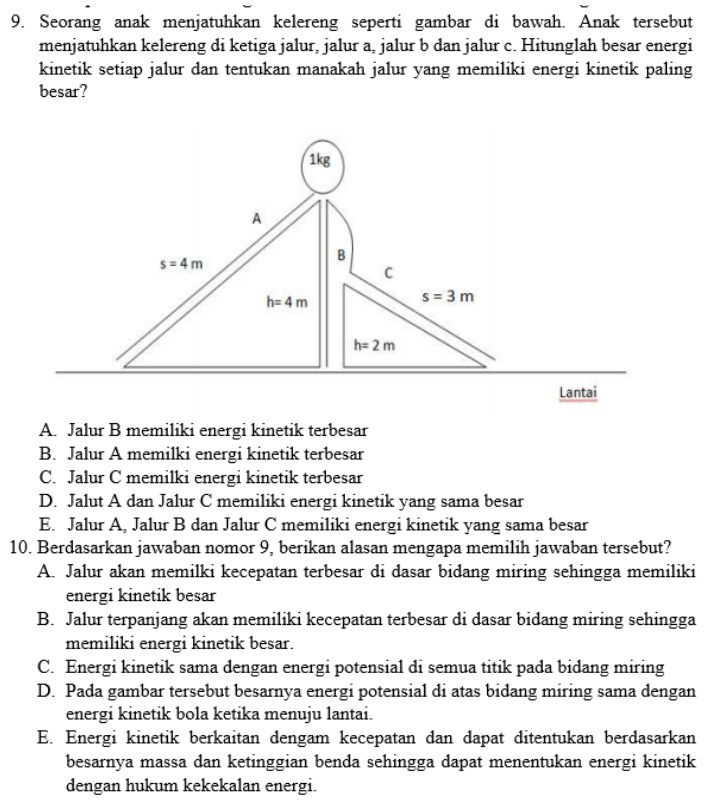

Figure 5. Questions number 9 and number 10
The number of respondents who could answer correctly to question number 9 was only four respondents, while for question number 10 , there were no respondents who answered correctly. The picture of question 9 shows that the trajectories $\mathrm{A}, \mathrm{B}$, and $\mathrm{C}$ have the same height. Many respondents assumed that the $\mathrm{A}, \mathrm{B}$, and $\mathrm{C}$ lines had different heights. Many respondents chose answer $\mathrm{B}$. To determine the kinetic energy of an object, use a formula.

$$
\begin{aligned}
E p_{1}+E k_{1} & =E p_{2}+E k_{2} \\
E p_{1}+0 & =0+E k_{2} \\
E p_{1} & =E k_{2}
\end{aligned}
$$

(Giancoli, 2014)

When the ball is on the floor, the amount of kinetic energy is determined by the potential energy determined by its height, mass, and gravitational acceleration. Since the mass and gravity of each marble are assumed to be the same, paths $A, B$, and $C$ have the same kinetic energy because each path has the same height as the floor. So the correct answer is E.

In case number 10, none of the respondents answered correctly. Many respondents choose to answer B because the respondent thinks that if an object moves along the longest path, it will have significant kinetic energy. The respondent's assumption about this does not seem right because based on case number 9, the kinetic energy on an inclined plane can be determined using the potential energy formula of an object which only depends on the mass, acceleration due to gravity, and height of the object and does not depend on the length of the path, so the correct answer is D.

These results indicate that the respondent has not been able to capture information verbally and only focuses on the existing formula so that when given the questions in the form of revealing the reason, the respondent is challenging to answer. Respondents also have not been able to link the relationship between the law of conservation of energy with potential and kinetic energy. In questions 9 and 10, respondents answered using the kinetic energy formula only, and it is not related to the law of conservation of energy. In terms of work and 
energy, respondents thought that the material provided was too difficult if the teacher delivered it only through writing. Respondents thought it would be easy to understand the material if delivered directly via video or video calls. This statement follows research from Abidin (2020), which states that students can understand direct learning material because the delivery of learning material delivered directly by the teacher is more straightforward, more detailed, easy to understand. If there is a material that is not understood, it can directly interact with the teacher through question and answer with the teacher, whereas during online learning, there is rarely direct interaction between students and teachers.

The findings of this study also show the obstacles experienced by respondents when doing online learning during the Covid-19 pandemic.
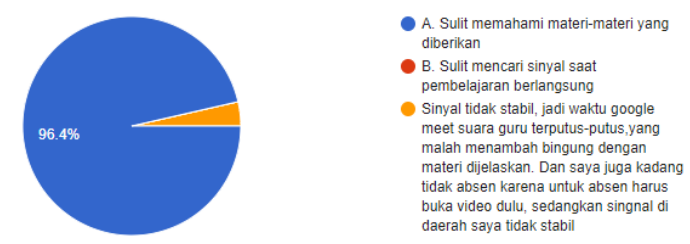

Figure 6. Obstacles faced when doing online learning

Figure 6 illustrates the obstacles experienced by respondents when doing online learning. 96.4\% of respondents stated that the obstacles faced were difficulties in understanding the material provided. In terms of work and energy, respondents think it is too difficult to understand work and is associated with energy changes. Respondents find it challenging to relate the relationship between the law of conservation of energy with potential energy and kinetic energy. If there is a question concerning the law of conservation of energy, the respondent will answer directly without relating it to the law of conservation of energy. Respondents also find it difficult to answer questions in the form of statements, and they prefer to answer questions with formulas directly, not questions of application. This problem is what makes respondents less familiar with the concepts of work materials and energy. Another factor that becomes an obstacle is that there is much material provided, so that it is challenging to keep understanding the material, and the large number of assignments given by the teacher makes students feel short of time. Respondents also assumed that they easily forget material and only learn if there is a test. Napsawati's research (2020) states that students who find it difficult to understand material related to calculations and students find it challenging to express difficulties to the teacher through messages. In addition to the difficulty of understanding the material, respondents also experienced problems with the internet network and limited quotas. Respondents who live in rural areas have difficulty following online lessons because there is difficulty getting a signal at their place of residence, so they have to go where there is a signal. Mustakim's research results (2020) state that e-learning is very dependent on the availability of the internet network. Therefore, a good internet network is needed and the availability of sufficient quotas to access e-learning properly.

\section{CONCLUSION}

Based on the analysis results, it can be concluded that online-based physics learning during the Covid-19 pandemic at SMA Negeri 2 Ponorogo on work and energy materials was effective. Online learning during the Covid-19 pandemic often uses the Whatsapp platform and school e-learning websites. The teacher also uses several media such as books/modules, powerpoints, and videos to attract students to more easily understand the material. More than $50 \%$ of respondents participate in online learning because teachers use interesting teaching materials such as books/modules, Powerpoints, and exciting videos. Respondents also argued that flexible lesson hours also influenced their interest in learning. More than $40 \%$ of respondents are not interested in participating in online learning because physics is considered boring for respondents. The cognitive test results show that the respondents do not understand the material provided by the teacher because the mean value of the test is $<60$ and does not meet the passing criteria. The obstacles faced by students in online learning were that $96.4 \%$ of 
students had difficulty understanding the material and questions related to statements, as well as limited data quotas and slow internet networks.

\section{REFERENCES}

Abidin, Z., Hudaya, A., \& Anjani, D. (2020). Efektivitas Pembelajaran Jarak Jauh Pada Masa Pandemi Covid-19. Research and Development Journal of Education, 1(1), 131-146.

Arizona, K., Abidin, Z., \& Rumansyah, R. (2020). Pembelajaran Online Berbasis Proyek Salah Satu Solusi Kegiatan Belajar Mengajar Di Tengah Pandemi Covid19. Jurnal Ilmiah Profesi Pendidikan, 5(1), 64-70.

Covid19.go.id. Accessed on 25 March 2021.

Daheri, M., Juliana, J., Deriwanto, D., \& Amda, A. D. (2020). Efektifitas Whatsapp Sebagai Media Belajar Daring. Jurnal Basicedu, 4(4), 775-783.

Giancoli, Douglas C.. 2014. Fisika: Prinsip dan Aplikasi Edisi ke 7 Jilid 1. Jakarta: Erlangga

Hikmat, H., Hermawan, E., Aldim, A., \& Irwandi, I. (2020). Efektivitas Pembelajaran Daring Selama Masa Pandemi Covid-19: Sebuah Survey Online. LP2M.

Kanginan, Marthen. 2007. Fisika untuk SMA Kelas X Semester 2. Jakarta: Erlangga

Kurniawan, W. (2021). Kompetensi Guru dalam Pembelajaran PAI pada Masa Pendemi Covid-19 di SMA Negeri 11 Kota Bengkulu (Doctoral dissertation, IAIN BENGKULU).

Kusuma, Y. A. (2020). Efektivitas Penggunaan Aplikasi Quizizz Dalam Pembelajaran Daring (Online) Fisika Pada Materi Usaha Dan Energi Kelas X MIPA Di SMA Masehi Kudus Tahun Pelajaran 2019/2020. Sanata Dharma University.

Mustakim, M. (2020). Efektivitas Pembelajaran Daring Menggunakan Media Online Selama Pandemi Covid-19 Pada Mata Pelajaran Matematika. Al asma: Journal of Islamic Education, 2(1), 1-12.
Napsawati, N. (2020). Analisis Situasi Pembelajaran Ipa Fisika Dengan Metode Daring Di Tengah Wabah Covid-19. Karst: Jurnal Pendidikan Fisika Dan Terapannya, 3(1), 6-12.

Nurdin, N., \& Anhusadar, L. (2020). Efektivitas Pembelajaran Online Pendidik PAUD di Tengah Pandemi Covid 19. Jurnal Obsesi: Jurnal Pendidikan Anak Usia Dini, 5(1), 686-697.

Oktavian, R., \& Aldya, R. F. (2020). Efektivitas Pembelajaran Daring Terintegrasi di Era Pendidikan 4.0. Didaktis: Jurnal Pendidikan dan Ilmu Pengetahuan, 20(2).

Nasution, P., \& Kadri, M. (2019). Pengaruh Model Pembelajaran Roblem Based Learning Berbasis Edmodo Terhadap Hasil Belajar Siswa Pada Materi Usaha Dan Energi. Jurnal Ikatan Alumni Fisika Universitas Negeri Medan, 5(4), 52-57.

Purwanto, A., Pramono, R., Asbari, M., Hyun, C. C., Wijayanti, L. M., \& Putri, R. S. (2020). Studi Eksploratif Dampak Pandemi COVID-19 Terhadap Proses Pembelajaran Online Di Sekolah Dasar. EduPsyCouns: Journal of Education, Psychology and Counseling, 2(1), 1-12.Covid19.go.id diakses pada 25 maret 2021

Rachmat, A., \& Krisnadi, I. (2020). Analisis Efektifitas Pembelajaran Daring (Online) Untuk Siswa SMK Negeri 8 Kota Tangerang Pada Saat Pandemi Covid 19. Magister Teknik Elektro Universitas Mercu Buana, 1-7.

Raharja, Bagus. 2014. Panduan Belajar Fisika: Kelas X/2. Jakarta: Yudhistira.

Rasyidah, K., Supeno, S., \& Maryani, M. (2018). Pengaruh Guided Inquiry Berbantuan Phet Simulations Terhadap Hasil Belajar Siswa Sma Pada Pokok Bahasan Usaha Dan Energi. Jurnal Pembelajaran Fisika,7(2), 129-134.

Wajong, A. D., Ridwan, R., \& Sangi, N. (2020). Efektivitas Penggunaan Pembelajaran Daring Edmodo Berbantuan Quizstar untuk Meningkatkan Hasil Belajar 
Mahasiswa. Attractive: Innovative

Education Journal, 2(3), 49-60.

idoyoko, Eko. 2009. Evaluasi Program Pembelajaran. Yogyakarta: Pustaka Pelajar

Yelensi, Y., Wiyono, K., \& Andriani, N. (2020). Efektivitas Penggunaan Video Pembelajaran Materi Usaha Dan Energi Berbasis Permainan Tradisional. Jurnal Pijar MIPA, 15(1), 1-6.

Yunita, E., \& Suprapto, N. (2021). Analisis Kelayakan Video Pembelajaran Fisika Berbasis Platform Youtube pada Materi Usaha dan Energi. 